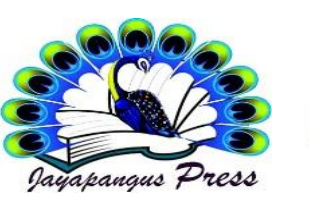

\title{
Ganaya:
}

Jurnal Tlmu Sasial dan \#umaniara Jayapangus Press

http://jayapanguspress.penerbit.org/index.php/ganaya Vol. 4 No. 2 (2021)

\section{Analisis Dampak Perubahan Media Promosi Pada Restoran Siap Saji}

\author{
Aviza Dwi Amalia \\ Program Studi Magister Ilmu Komunikasi Universitas Diponegoro \\ avizadwiamalia@students.undip.ac.id
}

\begin{tabular}{l}
\hline Keywords: \\
\hline Digital Media, \\
Youtube \\
Platform, \\
Advertising \\
\hline
\end{tabular}

\begin{abstract}
Utilizing digital media, especially the YouTube platform in advertising, provides convenience and cost savings incurred by business people, including fast-food restaurants such as Pizza Hut, which use the YouTube platform to promote their products, especially in the current Covid-19 pandemic era. The short duration and interesting and unique presentations make it easier for audiences to receive message information conveyed through advertisements. Digital marketing strategy is used because it is easier for producers to influence consumers. With the various conveniences provided by digital media, it certainly makes business people turn to digital media in promoting their products. This paper aims to find out how the impact of the existence of digital media which has experienced a shift from using television is now turning to digital media, especially the YouTube platform as a tool for promotion. Using qualitative methods and literature review. The results of the study with the presence of digital media for shopping advertisements experienced a significant increase in the presence of elements that make it easier for consumers to remember the messages conveyed through advertisements with the repetition of words in each advertisement. With digital media through the YouTube platform, of course, it is very easy considering that the growth of social media users is getting higher day by day
\end{abstract}

Kata Kunci:

Media Digital, Platform youtube, Iklan

\begin{abstract}
Abstrak
Memanfaatkan media digital khususnya platform youtube dalam beriklan memberikan kemudahan serta adanya penghematan biaya yang dikeluarkan oleh para pebisnis tidak terkecuali restoran siap saji seperti Pizza Hut yang memanfaatkan platform youtube dalam mempromosikan produk nya terlebih diera pandemi Covid-19 saat ini. Durasi yang singkat dan penayangan yang menarik dan unik memudahkan bagi khalayak dalam menerima informasi pesan yang disampaikan melalui iklan. Strategi digital marketing digunakan karena lebih mudah bagi produsen dalam mempengaruhi konsumen. Dengan berbagai kemudahan yang diberikan oleh media digital tentu membuat
\end{abstract}


para pebisnis beralih ke media digital dalam mempromosikan produknya. Pada makalah ini bertujuan guna untuk mengetahui bagaimana dampak dari adanya media digital yang mengalami perpindahan yang semula menggunakan televisi kini beralih ke media digital khsusnya platform youtube sebagai alat untuk promosi. Menggunakan metode kualitatif dan kajian studi literatur. Hasil penelitian dengan adanya media digital iklan belanja mengalami kenaikan secara signifikan adanya elemen yang memudahkan konsumen dalam mengingat pesan yang disampaikan melalui iklan dengan adanya pengulangan kata disetiap iklan. Dengan media digital melalui platform youtube tentu snagat memberikan kemudahan mengingat pertumbuhan pengguna media sosial saat ini semakin hari semakin tinggi.

\section{Pendahuluan}

Kemajuan teknologi tidak hanya mempermudah dalam menerima dan menyebarkan informasi akan tetapi memudahkan para pebisnis untuk dapat mengembangkan usaha mereka. Kehadiran new media saat ini tentu sangat memudahkan bagi para pebisnis dalam mempromosikan usaha mereka terlebih disaat situasi pandemi saat ini. Kehadiran new media memang sangat memudahkan guna untuk mempromosikan usaha mereka karena dengan memanfaatkan media sosial sebagai alat untuk dapat mempromosikan tentu sangat membuat kemudahan dan membuat biaya yang dikeluarkan jauh lebih hemat jika dibandingkan dengan membuat promosi atau iklan melalui televisi. Rusmayanto dalam (Prastianto, Julian, \& Safitri, 2019), mengatakan Strategi digital marketing merupakan suatu alat yang digunakan oleh para produsen untuk mempromosikan produk yang mereka miliki melalui media sosial atau media elektronik lainnya, dengan jangkauan sasaran yang lebih banyak serta tetap mengedepankan strategi pemasaran yang telah ditentukan.

Seiring dengan perkembangan teknologi media digital saat ini mendapatkan pandangan yang positif karena jika dilihat saat ini komunikasi pemasaran suatu produk melalui media sosial memunculkan pandangan bahwa penyampaian iklan melalui media sosial cenderung lebih banyak disukai oleh masyarakat. Hal ini juga dilakukan oleh olahan makanan siap saji seperti Pizza Hut yang memanfaatkan media digital dalam melakukan promosi khususnya di platform youtube. Penyajian yang unik dan menarik dalam membuat iklan di media sosial tentu akan memudahkan para khalayak dalam menerima iklan tersebut. Dengan mengandalkan media sosial tentu membuat para pebisnis berlomba - lomba menampilkan tampilan iklan yang dikemas secara singkat 
padat dan mudah diterima oleh khalayak, karena yang kita tahu bahwa masyarakat Indonesia khususnya lebih menyukai iklan yang dikemas secara menarik di media sosial. Menurut Anusha dalam (Eka Santi, 2020) dengan kehadiran internet tidak hanya untuk menerima dan menyebarkan informasi tetapi salah satunya digunakan untuk sebagai alat membuat iklan, dengan menggunakan internet dalam menyebarkan iklan tentu tidak menghabiskan biaya yang banyak. Internet mampu menjangkau seluruh lapisan khalayak secara luas dengan tidak adanya batasan waktu. Media sosial tentu memberikan kecepatan dalam menyebarkan iklan, tidak jarang banyak iklan yang dipromosikan atau disebarkan dengan menggunakan media sosial sebagai salah satu inovasi dalam mempromosikan iklan kepada khalayak.

Akses kemudahan yang diberikan oleh media sosial tentu membuat para produsen beralih dalam mempromosikan produk mereka yang semula melalui penyiaran terestial kini banyak produsen yang beralih ke media digital dalam mempromosikan produk mereka. Biaya murah dan jangkauan khalayak luas yang ditawarkan oleh media sosial mampu menyingkirkan media yang terlebih dahulu digunakan dalam membuat iklan, oleh karena itu tidak heran jika pertumbuhan media sosial berkembang begitu pesat saat ini. Semakin menarik iklan yang dibuat oleh suatu produk kedalam media sosial tentu membuat khalayak akan lebuh mudah tertarik dan melakukan proses belanja online berdasarkan dari iklan yang ditayangkan. Dilansir dari (Lubis, 2020) nielsen.com pada tahun 2019 belanja iklan terbesar dengan total belanja iklan sebanyak 10,3 Trilliun dengan begitu mengalami kenaikan secara signifikan mencapai 2\% sepanjang tahun 2019 . Dapat dilihat bahwa pertumbuhan iklan melalui media digital atau media sosial dari tahun ke tahun terus mengalami kenaikan tidak heran jika semakin banyak produk yang kita jumpai di berbagai platform media sosial seperti Youtube salah satunya. Hal serupa juga sama pada tahun 2017 berdasarakan data dari nielsen.com yabg dilansir dari trendingbisnis.com (Trendingbisnis, 2020) dimana pertumbuhan belanja iklan di televisi terjadi kenaikan, iklan ditelevisi tetap mengalami kenaikan meski pertumbuhan media digital semakin berkembang, dengan total $80 \%$ belanja iklan. Akan tetapi meski media penyiaran televisi mendapatkan iklan yang masih tinggi, pertumbuuhan iklan di media televisi cenderung turun jika dilihat dari tahun sebelumnya.

Iklan merupakan suatu komunikasi yang disampaikan baik media cetak maupun media massa yang mengiklankan yang berkaitan dengan iklan komersil maupun personal. Penayangan iklan tidak hanya sekedar menayampaikan pesan tetapi juga 
memperkenalkan kepada khalayak mengenai suatu perusahaan atau untuk menawarkan produk kepada para calon konsumen. Menurut Rossiter dan Percy,1997 (dalam (Juditha, 2017)) menyatakan bahwa dengan penyampaian pesan melalui iklan maka dengan cepat konsumen lebih mudah tertarik dan mengenal produk tersebut, oleh karena itu ketika suatu perusahaan memasarkan produk melalui iklan yang disampaikan lewat media sosial akan lebih cepat ditangkap oleh khalayak, karena iklan bagian dari salah satu pemasaran suatu produk.

Platform media sosial Youtube menjadi salah satu platform media sosial yang sering digunakan oleh khalayak dalam mengisi waktu luang mereka. Tidak hanya sekedar sebagai sarana hiburan dalam mengisi waktu luang, youtube juga sebagai salah satu platform media sosial yang menyampaikan berbagai macam informasi serta tiips dan trik seputar kehidupan. Tidak heran jika youtube menjadi salah satu media sosial yang paling diminati oleh khalayak. Dengan melihat perkembangan tersebut maka para produsen dengan mudah memasarkan atau mempromosikan produk mereka melalui media digital salah satunya youtube. Banyak produsen yang memanfaatkan media ini sebagai alat untuk mempromosikan produk mereka, yang semula mempromosikan produk melalui televisi kini banyak produsen yang beralih mempromosikan produk nya kepada calon konsumen mereka dengan memanfaatkan media digital atau media sosial. Menurut pandangan (Kotler \& Keller, 2012) mengatakan jika dengan meenggunakan media sosial dapat mempermudah para produsen dalam memasarkan produk kepada calon konsumen melalui iklan sehingga informasi atau pesan yang disampaikan dapat berupa teks, gambar dan audio.

Youtube hadir dengan memberikan kemudahan dan keunggulan jika dibandingkan dengan media penyiaran televisi, dimana pada saat penayangan iklan dalam platform youtube cenderung lebih tranpasran dalam menayangkan jumlah audiens hal ini tentu sangat berbeda dengan media penyiaran televisi yang cenderung tidak transparan dalam menayangkan jumlah audiens, kita akan mendapatkan jumlah audiens berdasarkan data dari Nielsen berbeda dengan platform youtube yang tidak memerlukan data dari Nielsen dalam menayangkan jumlah audiens. Hal inilah yang menyebabkan produsen lebih senang untuk melakukan promosi di media digital.

Pertumbuhan iklan melalui media sosial dapat menaikan ekonomi Indonesia yang dilihat semakin bertumbuh dengan pesat, dengan digunakannya strategi pemasaran melalui platform youtube tentu dapat meningkatkan perekonomian dalam hal ini adalah 
iklan. Dengan iklan tentu membuat pesan atau informasi yang disampaikan akan semakin mudah diterima oleh khalayak. Menurut pendapat Rizal dan Furinto,2009 (dalam (Wirasari \& Ferdiana, 2018)) mengemukakan pesan iklan merupakan suatu cara yang digunakan untuk dapat memberikan informasi, dengan iklan maka usaha dalam memperoleh serta untuk meningkatkan kualitas maka pesan iklan biasanya dipersiapkan secara matang sehingga pesan iklan yang akan disampaikan dapat diterima oleh khalayak dan dapat menjadi referesni konsumen sebelum memutuskan membeli suatu produk. Dengan adanya iklan tentu dapat mempengaruhi konsumen sebelum memutuskan untuk membeli suatu brand atau produk yang mereka inginkan, tidak hanya itu saja iklan juga dapat memberikan gambaran kepada khalayak serta dapat memberikan rekomendasi terhadap suatu produk. Pesan iklan juga dapat bersifat membujuk atau mempengaruhi khalayak agar memberi produk.

Jika kita lihat dengan kondisi saat ini maka dapat dilihat jika iklan melalui media digital tentu mengalami kenaikan ditahun 2020, dimana hal ini akan berpontensi terjadinya lonjakan pada iklan yang terjadi dimedia diigtal. Berdasarkan data dari riset dari Nielsen yang dilansir dari lokadata.id (Hidayatullah, 2020) menunjukkan adanya pertumbuhan belanja iklan.

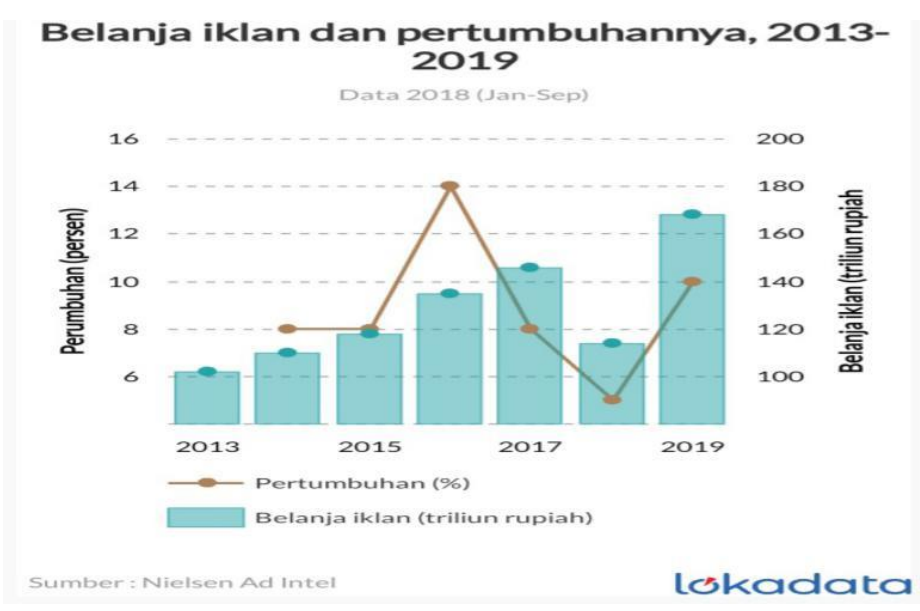

Gambar 1 Belanja iklan dan pertumbuhannya

Sumber: lokadata.id

Berdasarkan gambar diatas yang diperoleh dari Nielsen, jika pada tahun 2019 mengalami kenaikan dengan adanya iklan di media digital. Iklan media digital memiliki pengaruh terhadap keputusan pembelian. Dengan peningkatan yang terjadi secara signifikan dapat dilihat jika pertumbuhan dengan belanja iklan kian meningkat, mengingat semakin banyak yang mengakses media digital dan media sosial sehingga membuat para pebisnis lebih memilih untuk melakukan iklan dengan menggunakan 
media digital. Para penikmat media penyiaran televisi tidak akan berkurang, karena media penyiaran televisi masih dianggap sebagai medium yang memiliki pengaruh terhadap masyarakat.

Ada beberapa penelitian sebelumnya yang membahas mengenai "Iklan Yang Efektif Sebagai Strategi Komunikasi Pemasaran" yang dilakukan oleh Ambar Lukitaningsih menyebutkan bahwa iklan termasuk kedalam salah satu strategi pemasaran suatu produk yang banyak dilakukan oleh para pebisnis, banyak para pengusaha yang memasang iklan pada media terlebih media online saat ini berkembang cukup pesat sehingga iklan di media online akan diarasa jauh lebih efektif jika dibandingkan memasang iklan di televisi. Hasil penelitian menunjukkan iklan mampu menciptakan komunikasi yang efektif bagi konsumen karena dengan menggunakan iklan sangat menguntungkan bagi pihak perusahaan dan sangat berfungsi dalam memasarkan produk dengan tampilan desain yang menarik tentu akan semakin mudah dalam menawarkan produk melalui tampilan iklan (Lukitaningsih, 2013).

Selanjutnya penelitian yang membahas mengenai "Strategi Kreatif Iklan ECommerce Blanja.com di Youtube untuk Memenangkan Hati Konsumen", peneltiian yang dilakukan oleh Velda Ardia menyebutkan bahwa saat ini banyak sekali persaingan bisnis terlebih diera kemajuan teknologi seperti saat ini tentu membuat para pebisnis online seperti Blanja.com harus mampu bersaing dengan para brand dan akun belanja online lainnya guna menarik hati konsumen, dengan menggunakan platform Youtube sebagai alat untuk mengiklankan produk mereka tentu mereka dituntut untuk dapat berkreativitas dalam memuat iklan dengan tepat sasaran. Hasil penelitian menunjukkan jika pesan iklan yang disampaikan melalui platform youtube menyampaikan jika kita sebagai manusia memang sangat membutuhkan belanja serta sangat tertarik dengan berbagai macam barang yang menarik, dengan penyampaian iklan melalui youtube juga dianggap efektif dalam menyampaikan pesan iklan terlebih penikmat Blanja.com merupakan generasi milenial oleh karena itu iklan melalui youtube dianggap sangat tepat sasaran (Ardia \& Fadilah, 2018).

Penelitian yang dilakukan oleh Jusuf Fadilla yang membahas mengenai "Strategi Periklanan Online Shop di Media sosial Instagram" dalam penelitian ini Jusuf membahas mnegenai dengan merebaknya online shop saat ini tentu membuat produsen dan konsumen terlibat langsung didalam proses penjualan, dengan adanya media sosial saat ini tentu memudahkan proses saling berbagi informasi satu sama lain, kemudian 
kehadiran media sosial juga memberikan kemudahan dalam mempromosikan lewat iklan online yang ditayangkan melalui Instagram. Hasil dari penelitian ini ialah adanya Strategi yang dilakukan oleh Garasi Barokah selaku produsen selalu meningkatkan strategi perikalanan didalam mengelola penjualan dimana media sosial dijadikan sebagai alat untuk mempromosikan karena komunikasi yang dilakukan melalui instagram memiliki kelebihan sehingga antara produsen dan konsumen dapat terlibat komunikasi secara langsung. Sehingga pesan iklan yang disampaikan mengenai penjelasan secara terperinci mengenai produk dapat mencapai tujuan yaitu tujuan nya guna untuk mempengaruhi konsumen agar mau membeli produk yang mereka tawarkan. Dengan menggunakan media sosial maka konsumen akan dipermudah dalam pengajuan komplain jika terjadi kesalahan didalam produk dan dapat juga melakukan transaksi secara langsung antara produsen dan konsumen.

Pembuatan makalah ini dilakukan bertujuan untuk mengetahui bagaimana dampak dari adanya media digital. Media penyiaran televisi yang semula menjadi alat untuk promosi kini mengalami perpindahan ke media sosial saat ini khususnya platform youtube mengalami peningkatan secara signifikan dari tahun ke tahun mengenai iklan yang ditayangkan di youtube dalam memasarkan produk terhadap khalayak.

\section{Metode}

Metode yang digunakan dalam penelitian ini menggunakan deskriptif kualitatif, menggunakan deskriptif kualitatif yang digunakan untuk menjelaskan dan menganalisis data yang didapatkan sehingga data tersebut menjadi suatu hal yang dapat dipahami, Sugiyono,2016:3 (dalam (Wirasari \& Ferdiana, 2018)). Dengan menggunakan penelitian kualitatif maka dapat memberikan penjelasan secara mendetail dan mendalam serta dapat menganalisis mengenai terjadinya perpindahan iklan yang semula dari media penyiaran televisi kini banyak beralih ke media digital. Dalam penelitian ini juga menggunakan studi literatur guna untuk dapat melengkapi serta dapat digunakan sebagai data pendukung dalam penelitian. Studi literatur dalam penelitian ini menggunakan buku yang membahas mengenai iklan di media digital, jurnal penelitian sebelumnya serta website hasil data survey yang berkaitan dengan iklan di media digital, youtube channel menjadi salah satu penunjang data dalam melihat jumlah iklan yang tayang. 


\section{Hasil dan Pembahasan}

Berdasarkan penjelasan yang sudah dijelaskan di pendahuluan diatas yang menjelaskan mengenai adanya perpindahan promosi produk yang semula dari media televisi kini beralih ke media sosial platform youtube, terbukti penonton platform youtube lebih banyak saat inij jika dibandingkan dengan penonton televisi. Jika dilihat dengan kondisi pandemi covid-19 saat ini banyak masyarakat yang lebih menyukai menyaksikan atau menonton acara melalui platform youtube. Berdasarkan dari data Jakpat yang dilansir dari lokadata.id bahwa disaat pandemi saat ini banyak masyarakat yang menghabiskan waktunya untuk menonton platform youtube

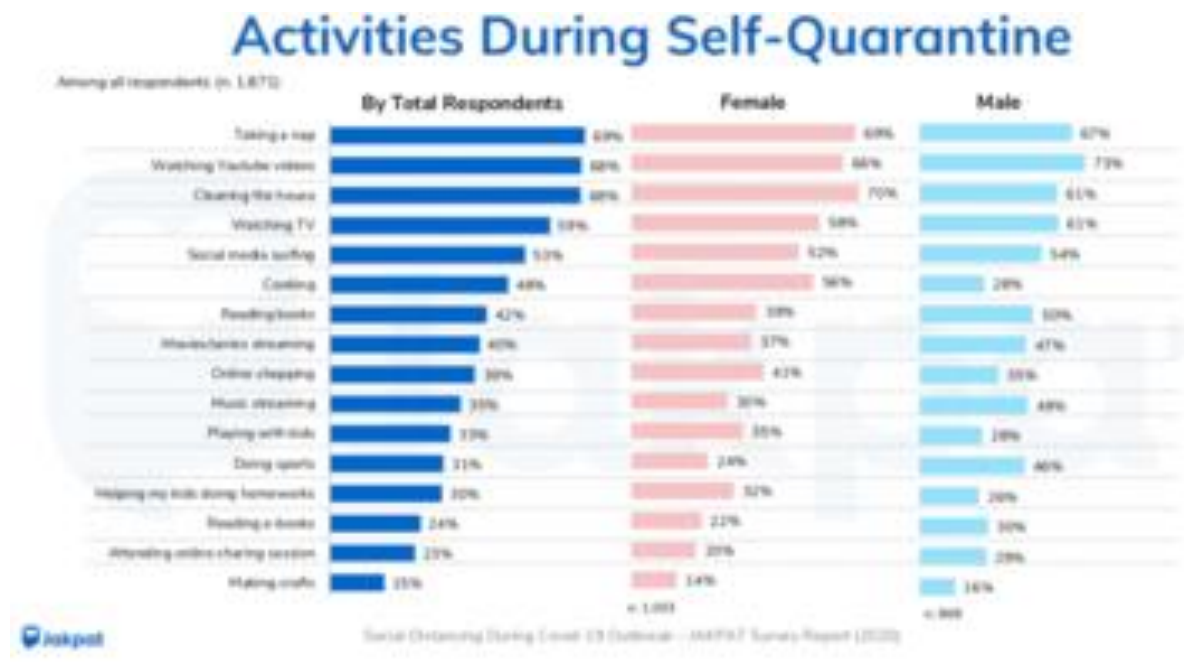

Gambar 2 Aktifitas yang dilakukan masyarakat selama dirumah, sumber: https://lokadata.id/artikel/penonton-dan-pengiklan-di-tv-mulai-beralih

Jika dilihat dari data diatas, platform youtube berada diposisi kedua dengan jumlah penonton youtube yang menanjak ketika masa pandemi saat ini hal inilah yang menjadikan perusahaan membuat lebih sering membuat promosi produknya melalui media sosial. Adanya peningkatan yang terjadi secara signifikan tentu berdampak kepada iklan yang dilakukan oleh sejumlah perusahaan. Karena dengan biaya yang murah tentu jangkauan yang akan dijangkau lebih luas dan lebih tepat sasaran. Terlebih disituasi saat pandemi Covid-19 saat ini banyak masyarakat yang melakukan kegiatan aktifitas dari rumah, untuk menghilangkan rasa bosan dan rasa jenuh maka banyak masyarakat yang menonton youtube. Ini menjadikan para pebisnis melihat peluang dengan mempromosikan produknya melalui media sosial.

Dengan menggunakan media sosial youtube menjadikan salah satu promosi iklan yang digunakan oleh guna untuk menarik konsumen. Berdasarkan data yang dilansir dari infodigimarket.com (Jauhari, 2018) beriklan melalui televisi relatif lebih mahal 
dibandingkan dengan beriklan melalui youtube, tayangan iklan di tv tergantung dari durasi penayangan iklan sedangkan beriklan di youtube diberikan fasilitas pay per click dimana produsen hanya akan membayar ketika penonton mengklik iklannya. Hal inilah yang membuat para produsen membuat iklan di media sosial karena mampu menarik calon konsumen dengan cepat dan mampu menarik perhatian calon konsumen untuk membeli suatu produk tersebut. Dengan tampilan yang hanya sebentar tapi pesan yang disampaikan mampu mempengaruhi para penonton dan penikmat media sosial platform youtube, jika dibandingkan dengan iklan ditelevisi dengan bayaran yang mahal dan tampilan durasi iklan yang cenderung lama dirasa kurang mempengaruhi penonton di televisi.

Menurut pendapat Tuten (dalam (Sa'diya, 2017)) media sosial merupakan salah satu alat yang digunakan untuk membuat iklan dalam mempromosikan suatu produk, dengan menggunakan media sosial tentu memudahkan bagi para produsen dalam memberikan keterangan mengenai suatu produk yang mereka tawarkan, dengan begitu akan jauh lebih memudahkan bagi para produsen agar dapat berinteraksi secara langsung kepada konsumen. Dengan media sosial tentu dapat membuat konsumen akan jauh lebih percaya terhadap suatu produk yang ditawarkan karena dengan media sosial mereka dapat berinteraksi secara langsung dengan produsen.

Berdasarkan data yang dilansir dari internasional.kontan.co.id (Kontan.co.id, 2020) pada tahun 2019 platform youtube menghasilkan pendapat sekitar 68,8 trilliun, pendapatan iklan yang didapatkan oleh youtube jauh lebih besar jika dibandingkan dengan media sosial lainnya. Jika kita lihat dari pendapatan youtube berhasil mendapatkan hasil yang fantastis hanya dari berupa iklan, hal ini terbukti jika pengguna youtube tentu lebih banyak dibandingkan dengan media sosial lain seperti Facebook yang hanya meraup keuntungan sebesar 288 triliun dari pendapatan iklan. Banyak penggguna yang lebih tertarik untuk menyaksikan acara melalui platform youtube dibandingkan dengan platform media sosial lainnya.

Tidak heran saat ini jika hampir seluruh pebisnis menggunakan platform youtube dalam mempromosikan produknya. Tak terkecuali pebisnis makanan seperti Pizza Hut yang ikut menayangkan pruduknya di youtube memberikan promosi pembelian, pada tanggal 20 Oktober 2020 dalam memperingati hari jadi dari Pizza Hut memberikan promosi disetiap pembeliaanya. Dalam perayaan ulang tahun Pizza Hut yang ke 13, dengan menyampaikan pesan di youtube dengan durasi iklan selama 2 menit tentu pesan 
yang disampaikan dapat mempengaruhi penonton. Berbeda dengan iklan lainnya, iklan Pizza Hut cenderung lebih sering tampil dan memberikan pesan kepada khalayak luas jika dalam rangka ulang tahun maka setiap pembelian produk mendapatkan promo atau potongan harga. Promosi makanan yang berada di media sosial memiliki daya tarik tersendiri dihadapan khalayak, banyak masyarakat yang menonton youtube hanya untuk mencari referensi mengenai makanan.

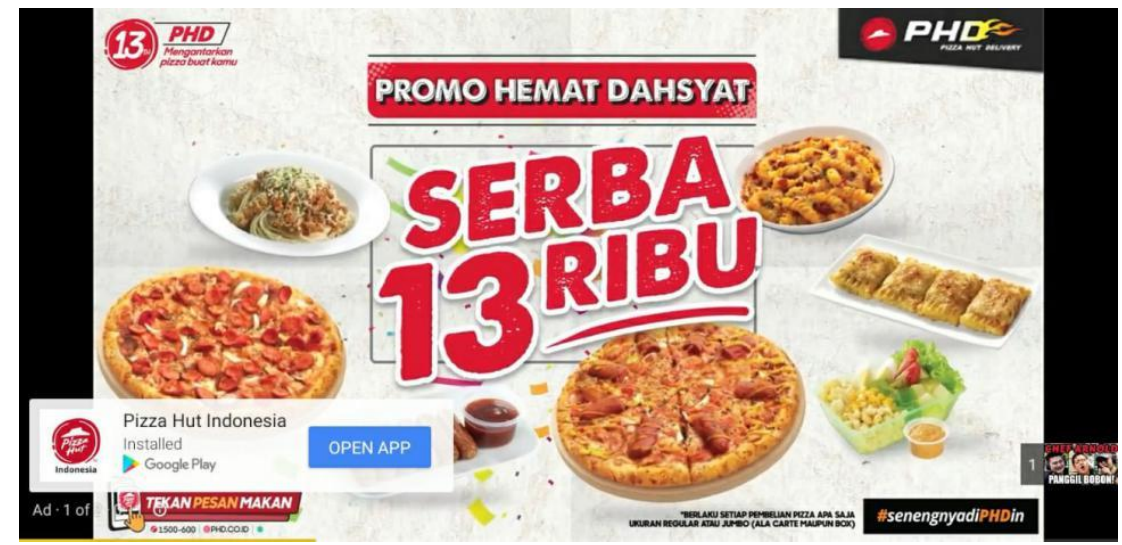

Gambar 3

Sumber: youtube

Dengan tampilan iklan seperti diatas yang ada di platform youtube tentu membuat penonton penasaran dengan promosi produk tersebut, sehingga pesan yang tersampaikan melalui iklan seperti diatas akan lebih sampai tepat sasaran kepada khalayak. Di sela sela menonton, khalayak disajikan dengan tampilan yang menggugah selera dengan tagline "Promo Hemat Dahsyat Serba 13 Ribu". Dengan tagline seperti itu tentu makna dari iklan yang ingin disampaikan bahwa sesungguhnya manusia membutuhkan makanan. Iklan di youtube tentu berbeda dengan iklan di media penyiaran televisi, di platform youtube khalayak tidak bisa mengganti ataupun menghindari iklan yang muncul disaat mereka sedang menonton tayangan. Jika dilihat dengan kondisi saat ini, restoran Pizza Hut termasuk ke dalam satu usaha yang mengalami dampak dari adanya pandemi covid-19, oleh karena itu strategi promosi yang dilakukan oleh Pizza Hut tentu dengan tidak hanya mengandalkan promosi di media penyiaran televisi tetapi juga memanfaatkan platform youtube.

Dengan memanfaatkan media digital tentu sangat membantu bagi usaha seperti Pizza Hut dalam tetap melakukan penjualan meski ditengah pandemi saat ini. Berdasarkan data yang di lansir dari katadata.co.id (Ekarina, 2020) pihak Pizza Hut tidak hanya memanfaatkan platform youtube salah satunya menjadi strategi yang digunakan 
oleh Pizza Hut guna menarik perhatian dari khalayak tetapi melakukan penjualan dengan turun ke jalan agar dapat tetap memperkerjakan karyawannya dikala pandemi. Dalam pembuatan iklan tentu tidak hanya memikirkan pesan yang disampaikan harus sampai kepada khalayak, tetapi juga harus memikirkan secara matang mengenai konsep yang akan digunakan dalam penyampaian pesan iklan tersebut. Iklan yang ditampilkan oleh brand Pizza Hut dibuat dengan semaksimal mungkin guna untuk menarik pelanggan, ada berbagai macam bentuk iklan yang menyajikan promo menarik.

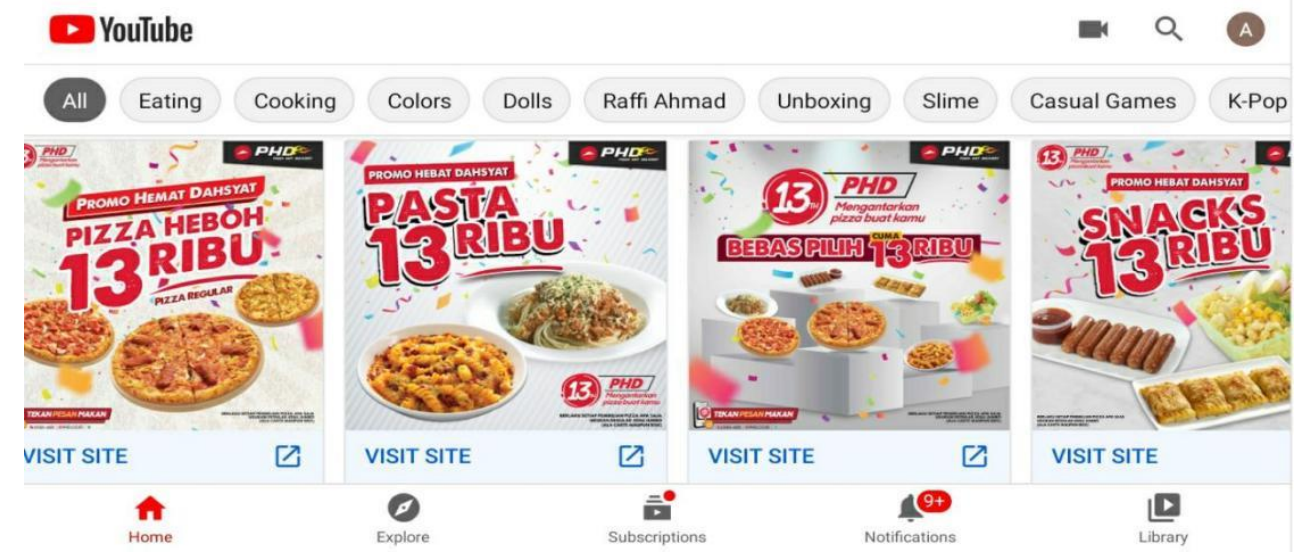

Gambar 4 Pizza Hut "Promo Hemat Dahsyat 13rb"

Sumber: youtube

Sasaran dari iklan ini tentu lebih kepada generasi millenial, karena pengguna youtube saat ini lebih banyak digandrungi oleh para kaum millenial. Tentu hal ini menjadi hal yang sangat meggiurkan bagi pemilik usaha seperti Pizza Hut dalam menayangkan iklan di Youtube. Terlebih dengan situasi Pandemi Covid19 saat ini, banyak masyarakat yang cenderung lebih sering menyaksikan tayangan di youtube dibandingkan di televisi. Menurut Helianthusonfri 2016 dalam (Kuspriyono, 2019) mnegatakan bahwa saat ini banyak sekali pilihan media guna untuk memuat iklan, jika dahulu hanya memanfaatkan tevelisi sebagai media membuat iklan maka saat ini media sosial youtube dapat menjadi alternatif dalam memuat iklan. Iklan yang disajikan di youtube mengenai promosi Pizza Hut tentu terdapat pula pada penyiaran televisi, akan tetapi di youtube iklan tersebut cenderung lebih sering muncul. Iklan yang ditampilan di youtube membuat adanya perbedaaan dengan iklan yang disajikan di media penyiaran. Dengan membuat konten iklan seperti itu tentu akan membuat iklan yang ditayangkan memiliki ke khasan khusus dalam menarik minat dari para konsumen.

Dalam mempromosikan suatu produk atau brand dapat membentuk citra dari perusahaan tersebut, dengan penampilan iklan yang semakin menarik maka citra yang 
ditampilkan dari perusahaan akan semakin baik. Dengan begitu konsumen dapat dengan mudah menikmati setiap tayangan dari produk yang ditampilkan. Tidak hanya sekedar menampilkan pesan, tetapi iklan juga dapat menguntungkan bagi konsumen, dengan begitu konsumen dapat dengan mudah merasakan keuntungan yang diperoleh dari produk yang di promosikan pihak Pizza Hut tentu sangat memiliki harapan yang sangat besar terhadap iklan yang dipromosikan dengan mendapatkan keuntungan dari iklan yang ditayangkan di platform youtube. Iklan yang disampaikan memiliki manfaat didalamnya dengan menekankan pada aspek gambar yang disajikan dengan berbagai macam bentuk gambar yang berbeda tentu memiliki maksud dan tujuan yang berbeda didalam setiap promosi nya. Menurut Tjiptono, Fandy dan Chandra 2012 dalam (Kuspriyono, 2019) mengatakan bahwa pemasaran dapat meliputi berbagai aspek yang diaman dalam setiap tindakan pemasaran dapat mempengaruhi permintaan terhadap produk, sebagai contoh dengan memberikan perbedaan harga, memasang iklan dan juga memberikan promo khusus disetiap produk.

Strategi pemasaran yang dilakukan oleh pihak Pizza Hut dengan menekankan kepada kualitas sebuah produk dengan begitu maka dapat mempermudah konsumen dalam memahami bentuk promosi tersebut dan membuat konsumen mengingat pesan yang disampaikan melalui iklan. Adanya elemen yang memudahkan konsumen dalam mengingat pesan yang disampaikan melalui iklan dengan adanya pengulangan kata disetiap iklan yaitu "Promo Hemat Dahsyat 13rb" yang diberikannya penekanan pada promo hemat dahsyat 13rb tentu sangat memudahkan bagi konsumen untuk mengingat, dan Pizza Hut membuat konten dimana setiap makananan yang disajikan didalam menu konsumen akan mendapatkan harga yang murah dan bersahabat, dengan begitu sangat diharapkan konsumen agar teru mengingat informasi yang disampaikan oleh Pizza Hut.

Dengan kemajuan teknologi yang ada saat ini, pihak Pizza Hut yang dilansir dari wartaekonomi.co.id (Pramudita, 2020) bahwa pihak Pizza Hut memanfaatkan teknologi yang ada saat ini dengan adanya data online konsumen yang mereka miliki tentu akan memudahkan para tim untuk dapat menggabungkan dan menyatukan serta mengembangkan kesimbangan audiens yang tentu mereka mengharapkan adanya hasil yang maksimal dengan harapan hasil berupa transaksi.

Dengan memberikan penekanan mengenai promo tentu diharapkan sangat membantu perusahaan dalam mengatasi permlasahan dampak dari pandemi covid-19, dengan begitu banyak masyarakat yang berminat untuk membeli setelah menyaksikan 
tayangan iklan yang ditampilkan di platform youtube. Informasi yang disampaikan oleh Pizza Hut bahwa mereka memiliki produk makanan dan service yang baik untuk para konsumen mereka, dengan penawaran spesial disetiap menu mampu memenuhi keinginan masyarakat dalam menyantap makanan yang memiliki harga bersahabat dengan mereka.

Dengan adanya perubahan gaya hidup yang terjadi pada masyarakat, tentu membuat para pebinsis dengan pintar memutar otak dalam berinovasi agar tetap menarik pembeli meski ditengah pandemi saat ini, strategi yang dilakukan para pebisnis berbedabeda salah satunya strategi yang dilakukan oleh Pizza Hut guna untuk menarik perhatian konsumen agar tetap membeli dan mengkonsumsi Pizza Hut dengan aman dan sehat dengan tetap menjaga kebersihan yang telah dianjurkan oleh Pemerintah. Strategi yang dilakukan bermacam - macam mulai dari menayangkan iklan mengenai sejumlah promo yang ada misalnya, iklan promo yang dilakukan hanya bisa digunakna ketika masyarakat membeli dengan melakukan pembelian online. Tentu pemasaran melalui media digital menjadi salah satu strategi yang digunakan oleh Pizza Hut sebagai restoran cepat saji yang terkena dampak dari pandemi Covid-19. Tidak hanya dengan melakukan promosi dilansir dari laman yonulis.com strategi yang dilakukan Pizza Hut dengan melakukan promosi melalui media digital ia juga menggaet influencer guna untuk menambah daya tarik pembeli.

Dengan media digital melalui platform youtube tentu snagat memberikan kemudahan mengingat pertumbuhan pengguna media sosial saat ini semakin hari semakin tinggi terlebih ditengah situasi pandemi saat ini, banyak masyarakat yang lebih sering menghabiskan waktunya dalam menyaksikan tayangan melalui youtube. Tingginya minat masyarakat dalam menyaksikan youtube sudah diprediksi sejak jauh hari mengingat akan kemudahan yang diberikan oleh media digital, berbeda dengan media penyiaran televisi.

\section{Kesimpulan}

Iklan yang ditayangkan oleh Pizza Hut di media digitial memiliki pesan yang dikomunikasikan dengan tulisan pada pesan "Promo Hemat Dahsyat". Kalimat yang digunakan menjadi sangat unik dan menjadi ciri khas dari iklan tersebut. Strategi yang dilakukan oleh tim dalam memberikan pesan lewat iklan tentu membuat iklan tersebut menjadi terlihat unik dan dengan adanya pesan iklan seperti itu diharapkan para konsumen dapat merasakan adanya hubungan dengan melalui pesan "Promo Hemat Dahsyat". Platform youtube dipilih karena menjadi media yang sangat efektif dikala 
pandemi saat ini, karena bagi pihak Pizza Hut pihaknya telah melakukan strategi guna menaikan proses penjualan mulai dari memberikan promosi sampai dengan melakukan kerjasama dengan berbagai aplikasi online guna untuk menaikan jumlah konsumen. Target dari iklan ini sebenarnya kepada generasi millenials sebagai pengakses youtube dengan jangkauan yang luas dan dapat diakses kapan saja dimana saja. Platform youtube menjadi numedia yang sangat disukai oleh para penontonnya dan berbagai kalanga, sehingga iklan di media digital menjadikan salah satu alasan pihak Pizza Hut untuk dapat mengiklankan Pizza Hut dengan memberikan tagline "Promo Hemat Dahsyat".

\section{Daftar Pustaka}

Ardia, V., \& Fadilah, F. N. (2018). Creative Ads Strategy of Blanja. Com To Win ECommerce Market Through Youtube. Perspektif Komunikasi: Jurnal Ilmu Komunikasi Politik Dan Komunikasi Bisnis, 2(2). Retrieved from https://jurnal.umj.ac.id/index.php/perspektif/article/view/3955

Eka Santi, D. (2020). Peran Online Advertising Pada Pemasaran Axis. Jurnal Ilmu Komunikasi, 6(1), 58. https://doi.org/10.35308/source.v6i1.1768

Ekarina. (2020). Misi Ganda Pizza Hut “Turun ke Jalan” saat Pandemi Corona Artikel ini telah tayang di Katadata.co.id dengan judul "Misi Ganda Pizza Hut Turun ke Jalan saat Pandemi Corona", https://katadata.co.id/ekarina/brand/5f69fa638f257/misiganda-pizza-hut-turun-ke-. Retrieved August 20, 2021, from https://katadata.co.id/ekarina/brand/5f69fa638f257/misi-ganda-pizza-hut-turunke-jalan-saat-pandemi-corona

Hidayatullah, T. (2020). Penonton dan pengiklan di TV mulai beralih. Retrieved October 20, 2020, from https://lokadata.id/artikel/penonton-dan-pengiklan-di-tv-mulaiberalih

Jauhari, M. F. (2018). YouTube Vs TV, Mana yang Lebih Efisien Untuk Beriklan? Retrieved August 20, 2021, from https://infodigimarket.com/youtube-vs-tv/ Juditha, C. (2017). Memahami Struktur Jaringan Media Sosial sebagai Cara Strategis Periklanan di Era Ekonomi Digital. Jurnal Pekommas, 2(1), 99-114. Retrieved from https://jurnal.kominfo.go.id/index.php/pekommas/article/view/2020110

Kontan.co.id. (2020). Pendapatan iklan YouTube sepanjang 2019 capai US\$ 15,15 miliar. Retrieved 20, August 2021, from https://internasional.kontan.co.id/news/pendapatan-iklan-youtube-sepanjang- 
2019-capai-us-1515-miliar?page=all

Kotler, P., \& Keller, K. L. (2012). Marketing Management (14th ed.). Upper Saddle River, N.J.: Pearson Prentice Hall.

Kuspriyono, T. (2019). Analisis Strategi Pemasaran Produk di Di YouTube Melalui Subscriber Tertinggi dan Kualitas Tayangan Iklan Terhadap Keputusan Pembelian Produk. Cakrawala - Jurnal Humaniora, 19(2), 165-172. https://doi.org/10.31294/jc.v19i2.5453

Lubis, M. (2020). belanja iklan 2019 ditutup dengan tren positif. Retrieved from https://www.nielsen.com/id/id/press-releases/2020/belanja-iklan-2019-ditutupdengan-tren-positif/

Lukitaningsih, A. (2013). IKLAN YANG EFEKTIF SEBAGAI STRATEGI KOMUNIKASI PEMASARAN. Jurnal Ekonomi Dan Kewirausahaan, 13(2), 116-129. Retrieved from http://ejurnal.unisri.ac.id/index.php/Ekonomi/article/view/670/576

Pramudita, B. A. (2020). Kompetisi Sudah Penuh, PHD Gunakan Teknologi $\begin{array}{llll}\text { Programmatic. } & \text { Retrieved } & \text { October 20 } & \text { from }\end{array}$ https://www.wartaekonomi.co.id/read306815/kompetisi-sudah-penuh-phdgunakan-teknologi-programmatic

Prastianto, E., Julian, F., \& Safitri, D. (2019). Web Series Marketing Communication Through Digital Traveloka. Jurnal Ilmu Komunikasi, 8(1), 16-21. https://doi.org/10.21070/kanal.v

Sa'diya, L. (2017). STRATEGI PROMOSI DI MEDIA SOSIAL INSTAGRAM TERHADAP KESADARAN MEREK DI ERA GENERASI Z. Journal of Management Studies, 11(2), 186-195. Retrieved from https://journal.trunojoyo.ac.id/kompetensi/article/view/3530/2601

Trendingbisnis. (2020). Youtube Lebih Dari TV, Yakin? Retrieved October 27, 2020, from https://trendingbisnis.com/index.php/dunia-media/24-youtube-lebih-daritv-yakin

Wirasari, I., \& Ferdiana, T. (2018). Strategi Kreatif Tema Pahlawan Dalam Iklan Media Sosial Bukalapak. Jurnal ATRAT, 6(2), 4-9. Retrieved from https://jurnal.isbi.ac.id/index.php/atrat/article/view/522/409 